\title{
Sideroblastic anemia
}

\author{
Bhandari $\mathrm{P}^{1}$, Hamal $\mathrm{R}^{2}$, Shrestha $\mathrm{A}^{3}$, Shrivastav $\mathrm{S}^{3}$ \\ ${ }^{I}$ Department of Internal Medicine, Tribhuvan University Teaching Hospital, Maharajgunj, Kathmandu, Nepal. \\ ${ }^{2}$ Department of Gastroenterology, Tribhuvan University Teaching Hospital, Maharajgunj, Kathmandu, Nepal \\ ${ }^{3}$ Department of Pathology, Tribhuvan University Teaching Hospital, Maharajgunj, Kathmandu
}

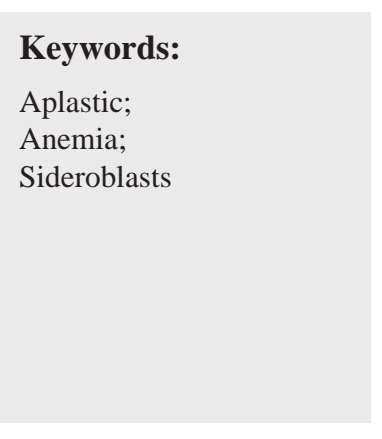

\begin{abstract}
Sideroblastic anemias are a heterogenous group of disorders that have as a common feature with the presence of ringed sideroblasts in the marrow. We present a case of young female, nursing student who presented with increasing palpitation, fatigue and exertional shortness of breath for the last one year. She had a low hemoglobin and high serum iron. Anemia with iron overload prompted us to do bone marrow study and there were 19\% ringed sideroblasts and iron overload fulfilling the diagnosis of sideroblastic anemia. We searched for secondary causes of ringed sideroblast but could not find any culprit. Her cytogenetics report was normal and genetic analysis was not done due to financial reason. Since the diagnosis 3 months back, patient is on pyridoxine, folic acid, deferasirox and still needs regular blood transfusion suggesting that she may be pyridoxine refractory and may develop iron overload.
\end{abstract}

\section{INTRODUCTION}

Sideroblastic anemia is a refractory anemia defined by the presence of many pathological ringed sideroblasts in the bone marrow. Sideroblastic anemia have as a common feature the presence of: (a) large number of pathologic sideroblasts in the marrow, which characteristically display abnormal mitochondrial iron accumulation in a circumnuclear position in erythroblast, these are referred to as ringed sideroblasts (b) ineffective erythropoiesis (c) increased levels of tissue iron (d) varying proportions of hypochromic erythrocytes in the blood. ${ }^{1}$ Sideroblastic anemia is diagnosed when 15 $\%$ or more of marrow erythroblasts are ringed sideroblasts. ${ }^{2}$

\section{Correspondence:}

Dr. Pragya Bhandari

Department of Internal Medicine

Tribhuvan University Teaching Hospital, Maharajgunj, Kathmandu, Nepal. Email: pragyabhandari2073@gmail.com

\section{Case Report}

Eighteen years-old female presented to us with abnormal feeling of her heart beat which increased on exertion for the last one year. She complained regular and rapid palpitations. There was no relation to change in posture. She gave history of undue fatigue and exercise intolerance. She felt short of breath on exertion. She also complained of occasional cramping and numbness of her extremities. She used to feel weak and dizzy during her work as a nursing student. Her symptoms started insidiously and were gradually progressive. She did not give history of chest pain, swelling of body, orthopnea, paroxysmal nocturnal dyspnea, yellowish discoloration of her eyes, frequent sore throats, excessive menstrual bleeding, bluish patches, joint pain, photosensitivity, and bluish or white discoloration of 
Table: 1 Hematological profile

\begin{tabular}{|c|c|c|c|c|c|c|c|c|c|}
\hline $\begin{array}{l}\text { Hb. } \\
\text { (gm\%) }\end{array}$ & $\begin{array}{c}\text { TC } \\
(109 / \mathrm{L})\end{array}$ & $\begin{array}{l}\text { DC } \\
(\%)\end{array}$ & $\begin{array}{l}\text { MCV } \\
\text { (fi) }\end{array}$ & $\begin{array}{l}\text { MCH } \\
\text { (pg) }\end{array}$ & $\begin{array}{l}\text { Retics } \\
(\%)\end{array}$ & $\begin{array}{l}\text { Serum iron } \\
\text { (ug/dl) }\end{array}$ & $\begin{array}{l}\text { TIBC } \\
\text { (ug/dl) }\end{array}$ & $\begin{array}{l}\text { Ferritin } \\
(\mathrm{ng} / \mathrm{ml})\end{array}$ & $\begin{array}{l}\text { IRON SAT- } \\
\text { URATION }\end{array}$ \\
\hline 6.6 & 6.6 & $\begin{array}{l}\text { N50, } \\
\text { L47 }\end{array}$ & 52 & 16 & $1.7 \%$ & 200 & 425 & $>1000$ & $47 \%$ \\
\hline
\end{tabular}

Table 2: Iron overload study of liver and heart

\begin{tabular}{lccccc}
\hline \multicolumn{3}{c}{ LIVER } & \multicolumn{3}{c}{ HEART } \\
\hline T2 & R2 & LIC & T2 & R2 & MIC \\
$1.3 \mathrm{~ms}$ & $767.9 \mathrm{~Hz}$ & $24.4 \mathrm{mg} / \mathrm{g}$ & $40.4 \mathrm{~ms}$ & $24.7 \mathrm{~Hz}$ & $0.49 \mathrm{mg} / \mathrm{g}$
\end{tabular}

T2: Relaxation time; R2: Relaxation rate (1/T2); LIC: Liver Iron Concentration (normal $=<2 \mathrm{mg} / \mathrm{g}$ ); MIC: Myocardial Iron Concentration (normal $=<1.16 \mathrm{mg} / \mathrm{g}$ )

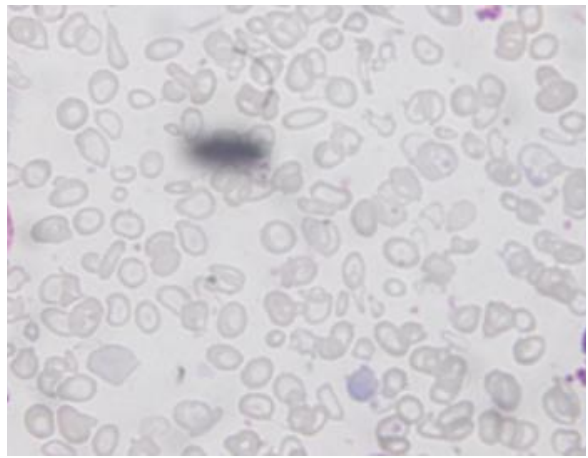

Figure 1: Peripheral blood smear shows microcytic hypochromic RBCs (Wright stain, X1000).

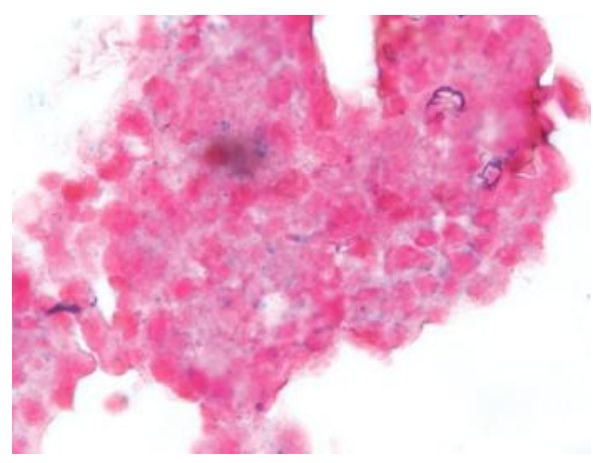

Figure 3: Bone marrow smear shows 4+ iron store (Perl's Prussian blue stain, X1000).

hand on exposure to cold. There was no history of exposure to any drug, alcohol, smoking or heavy metal. She is nonvegetarian by diet with normal dietary pattern. She is unmarried and does not have any high risk behaviour. Her menstrual period was irregular, with menstrual period every 2-3 months with normal blood flow for last one year. There was no significant family history.

She went to a cardiologist one year back because of the palpitations. Her hemoglobin was found to be low but the

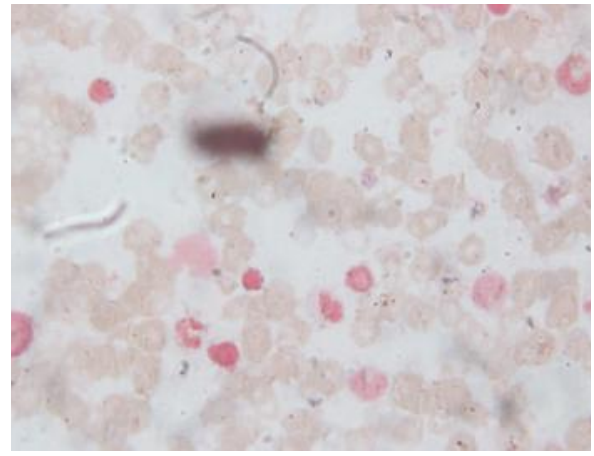

Figure 2: Bone marrow smear shows ringed sideroblast (arrow) (Wright stain, X1000).

rest of her cardiac evaluation including ECG and echo were normal. She was then referred to a physician for further evaluation which revealed high serum iron. The evaluation did not proceed any further at that time. One year after the initial visit to doctor her complaints increased and came for medical advice.

On examination she looked pale. There was no icterus, lymphadenopathy or edema.

Pulse was 92 beats per minute. Blood pressure was 110/70 $\mathrm{mmHg}$. Rest of the systemic examination was normal. Hematolgical investigations were performed along with iron profile. (Table 1) Serum ferritin level was very high (>1000ng/ml). Peripheral blood smear showed microcytic hypochromic picture (fig.1). Her LDH was $520 \mathrm{U} / \mathrm{L}$, uric acid-152 $\mu \mathrm{mol} / \mathrm{L}$ and erythropoietin level was $171 \mathrm{Miu} /$ $\mathrm{mL}$. Other tests like hemoglobin electrophoresis, Serum ceruloplasmin, liver function test, renal function tests, antinuclear antibodies lead were within normal limit. Bone marrow aspiration was performed under aseptic condition which showed cellular marrow with $4+$ iron and 19\% ring sideroblasts. No abnormal cell infiltrates or increased in blast or hemoparasites seen.(fig.2\&3) Iron overload study was done which showed following findigs. (Table 2) Patient 
was diagnosed as sideroblastic anemia and now is no deferoxmine, folic acid and pyridoxine $100 \mathrm{mg}$ OD. She is also on regular blood transfusion.

\section{DISCUSSION}

Cooley reported the first family with X-linked hypochromic microcytic anemia in $1945 .^{3}$ After several case reports, the term sideroblastic anemia was adopted. Sideroblastic anemia can be either hereditary or acquired. Hereditary form which is also called congenital sideroblastic anemia can be isolated or associated with genetic syndromes. Acquired form is associated with alcoholism, isoniazid, chloramphenicol or copper deficiency can be reversible or it can be clonal.

Kinetically, the sideroblastic anemias are characterized by ineffective erythropoiesis, like other erythroid disorders with defective cytoplasmic or nuclear maturation. Erythroid hyperplasia of the bone marrow is accompanied by a normal or only slightly increased reticulocyte count.

An almost constant feature of those sideroblastic anemias that are not reversible is an excess of total body iron. The serum iron concentration is increased, often to the point of complete saturation of transferrin, and the level of serum ferritin roughly reflects the degree of iron overload. ${ }^{4}$

In hereditary forms the anemia is usually characterized by a markedly hypochromic and microcytic blood picture. Our patient's RBC MCV was $52 \mathrm{fl}$ and $\mathrm{MCH}$ was $16 \mathrm{pg}$. In view of young age and absence of secondary causes, it is likely that she has pyridoxine resistance congenital sideroblastic anemia.

\section{CONCLUSION}

In our context where malnutrition and iron deficiency is highly prevalent, microcytic hypochromic anemia is mostly due to iron deficiency. Hence there is an inherent tendency to assume any microcytic hypochromic anemia as iron deficiency anemia especially in reproductive age female and thus prescribe iron therapy. As our case amply illustrates sideroblastic anemia can present as microcytic hypochromic anemia even though it is a relatively rare cause. Iron deficiency anemia and sideroblastic anemia are treated differently. Therefore it is important to evaluate thoroughly a case of microcytic hypochromic anemia with iron overload keeping sideroblastic anemia as one of the differentials.

\section{REFERENCES}

1. Liesveld JL, Lichtman MA, et al. Myelodysplastic syndromes. In: Kaushansky K, Lichtman MA, Seligsohn U, et al., editors. Williams hematology. Eighth. New York: McGraw-Hill Medical; 2010. pp. 1249-1276.

2. Hoffbrand AV, Catovsky D, et al. (eds), Postgraduate Haematology, 6 ed. West Sussex. WileyBlackwell. 2011. 468p.

3. Cooley TB. A severe type of hereditary anemia with elliptocytosis. Interesting sequences of splenectomy. Am J Med Sci 1945;209:5618. http://dx.doi.org/10.1097/00000441-194505000-00001

4. G Greer JP, Arber DA, Glader B, List AF, Means RT, Jr., Paraskevas F, et al., eds. Wintrobe's clinical hematology. 13 ed. Philadelphia: Wolters Kluwer/Lippincott Williams \& Wilkins; 2014. 2312p 